DOI: http://doi.org/10.21698/simi.2018.ab24

\title{
ENVIRONMENTAL ASSESSMENT OF A LOCATION INTENDED FOR IMPLEMENTATION OF AN INVESTMENT PROJECT
}

\author{
Bogdan Stanescu, Lidia Kim, Gina Traistaru, Adriana Cuciureanu, Gheorghita Tanase \\ National Research and Development Institute for Industrial Ecology, ECOIND, 71-73 \\ Drumul Podu Dambovitei, 060652, district 6, Bucharest, stanescubogdan2@gmail.com, \\ Romania
}

Keywords: environmental assessment, pollution sources, potential pollution

\section{Introduction}

The environmental quality of a site involves a set of general and local environmental and physical parameters that can affect humans and other organisms. A primordial aspect is given by human health that includes the quality of life that is equivalent to a clean, unpolluted environment.

The development needs of Bucharest, the capital of Romania are very high. In recent years, the interest of large investment firms in the construction of industrial buildings, logistic bases (warehouses) and offices has been noted. One of these companies present on the Romanian market has been oriented towards providing the clients with facilities in the transit areas, but not so far from the public transport facilities of Bucharest city. This international company has built and builds facilities, warehouses for adequate storage of vegetables, fruits, for electronics and household appliances, medicines, etc. All facilities are built to the highest quality standards and also offers office buildings for its clients in accordance with their needs.

To develop these facilities, they acquired a number of lands that were set aside and underwent major transformations being converted into industrial or commercial facilities. The environmental protection developer wanted to know in detail the quality of the environmental components for the purchased land so as to ensure that all the environmental requirements covered by the Romanian legislation are met. NRDIECOIND specialists made an objective assessment of the quality of the environmental components and submitted the conclusions of the investigations to the developer, assuring them that there are no prerequisites with a negative potential for the implementation of their development projects.

\section{Materials and methods}

The site analyzed is a land located near the city of Bucharest, in its West area, in the proximity of a road junction located on the A1 highway, Bucharest-Pitesti, km. 23, exit to Ghionea village, respectively un secondary road DC147.

The land area is about 10 hectares and was coded under the BUW14 label. The localization of the area investigated is shown in Figure 1.

The investigations aimed to make a complete analysis of the environmental factors, for a more thorough assessment in order to establish the initial conditions, respectively before starting the investment project in this zone. The proposed investigations for the BUW14 site are presented schematically in Figure 2. 


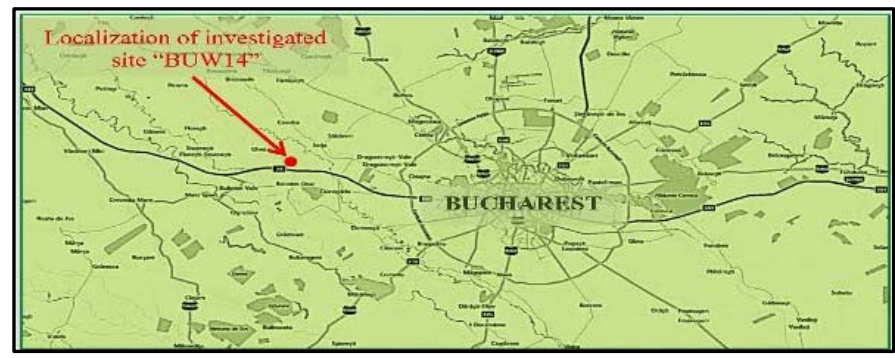

Figure 1. Localization of the investigated site BUW14

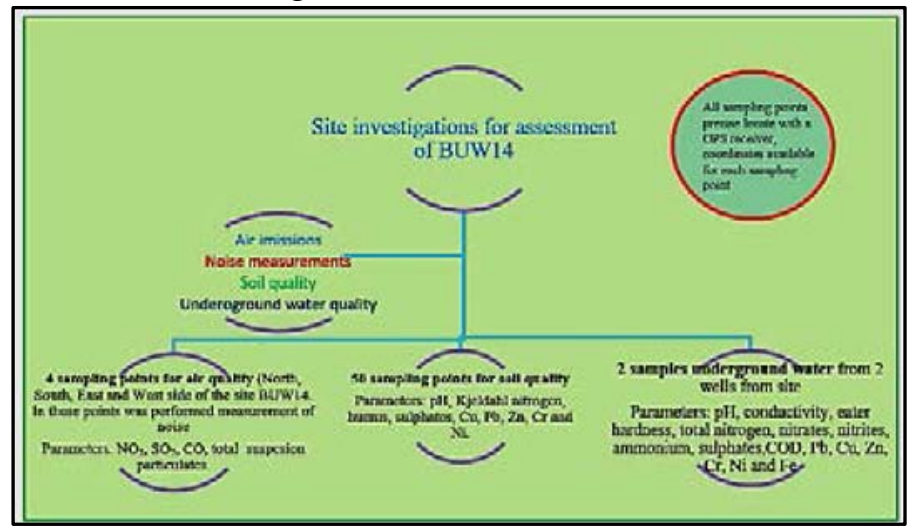

Figure 2. Site investigations data sheet BUW14

\section{Results and conclusions}

The assessment of the environmental components to determine the quality of a BUW14 -10 ha area on which an investment project is to be developed was made to provide the relevant environmental information before the project itself was carried out, there are all necessary assurances that the land purchased as a destination for logistic constructions was not previously affected by the pollution or the agricultural activities carried out on it. The assessment was carried out by air, soil, groundwater and noise level measurements and analysis, and objectively established that it was a unpolluted land, being certain premises for the development of the environment under the best environmental conditions. The general conclusions were synthesized in the form of a diagram for assessing the environmental conditions of BUW14, presented in Figure 3.

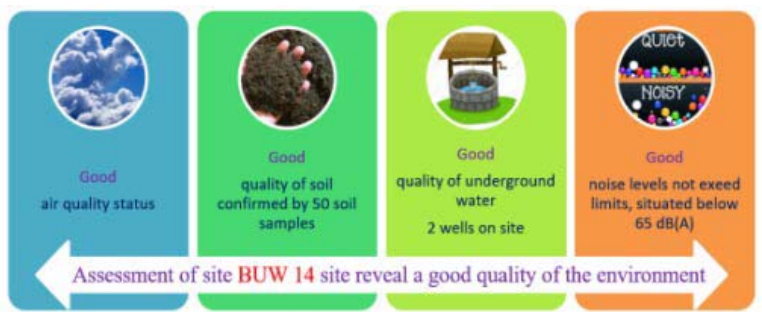

Figure 3. Site evaluation diagram

All the relevant environmental aspects of the BUW14 site evaluation have provided clear premisis without additional environmental costs to the owner, in order to be able to develop in optimal conditions his new projects that includes logistics and office building in best quality environment conditions. This site evaluation with a pronounced applicative character reveals once again how important the environmental assessment is made before implementing a new project. 